\title{
KAJIAN PROPORSI KETERLIBATAN PEREMPUAN (GENDER) DALAM USAHA TANI PADI DI KABUPATEN BANDUNG, SUBANG, DAN KARAWANG
}

\author{
Iwa Sungkawa \\ Mathematics and Statistics Department, School of Computer Science, Binus University \\ Jln. K.H. Syahdan No. 9 Palmerah, Jakarta Barat 11480 \\ iwasungkawa@yahoo.com
}

\begin{abstract}
This study aimed to evaluate the involvement of women in Rice Farming Enterprise in Regency of Bandung, Subang and Karawang in a government program of gender equality. Through the estimation of proportion and descriptive studies by comparing figures targeted by the government of at least $30 \%$, it can be evaluated that there is variability in all regencies. Further studies are analytical studies to determine the alleged intervals and hypothesis testing for proportions and to conduct studies by comparing observations and determined value by using the standard normal distribution. The results of the study shows that the role of women/gender in Rice Farming Enterprise is very dominant at each stage of planting, weeding and harvesting stages. For other stages such as land cultivation, Countermeasures Integrated Pest, irrigation and distribution, the women's role is less dominant. This information is expected to support the Agricultural Sector policy makers in developing women's empowerment and gender equity.
\end{abstract}

Keywords: proportions, estimation, hypothesis testing, standard normal distribution, women's empowerment

\begin{abstract}
ABSTRAK
Penelitian ini bertujuan untuk mengevaluasi keterlibatan perempuan pada Usaha Tani Padi di Kabupaten Bandung, Subang dan Karawang dalam program kesetaraan gender yang merupakan program pemerintah. Melalui pendugaan proporsi dan kajiannya secara deskriptif dengan membandingkan angka yang ditargetkan pemerintah minimal 30\% dapat dievaluasi kondisi yang ada di ketiga Kabupaten. Kajian lebih lanjut adalah kajian analitik untuk menentukan dugaan interval dan menguji hipotesis untuk proporsi dan melakukan kajiannya dengan menbandingkan hasil pengamatan dan nilai yang ditentukan dengan menggunakan sebaran normal baku. Hasil kajian menunjukan bahwa peranan perempuan/gender dalam Usaha Tani Pani sangat dominan pada tahapan kegiatan penanaman, penyiangan dan tahapan kegiatan panen. Untuk tahapan kegiatan lainnya seperti pengolahan lahan, Penanggulangan Hama Terpadu (PHT), pengairan dan pengangkutan peranan perempuan kurang dominan. Diharapkan informasi ini dapat mendukung para pengambil kebijakan Sektor Pertanian dalam menyusun program pemberdayaan perempuan dan kesetaraan gender.
\end{abstract}

Kata kunci: proporsi, estimasi, uji hipotesis, sebaran normal baku, peranan perempuan, kesetaraan gender 


\section{PENDAHULUAN}

Keikutsertaan perempuan (gender) merupakan ketentuan dan target pemerintah dalam melaksanakan pembangunan dalam berbagai sektor dan telah ditetapkan minimal 30\%. Jadi setiap sektor harus dan diwajibkan untuk melibatkan perempuan dalam melaksanakan kegiatannya. Dalam sektor pertanian, padi merupakan komoditi yang paling kompeten dan menentukan perkembangan perekonomian Indonesia, sehingga dalam kajian ini difokuskan untuk menelaah keterlibatan perempuan yang bekerja di Usaha Tani Padi. Futurolog John Naisbeth dan Patricia Aburdens dalam buku Megatrend 2000 telah meramalkan bahwa Abad XXI akan menjadi abad perempuan. Begitu pula Feminis Amerika Naomi Wolf, yang juga menyatakan bahwa abad tersebut sebagai era gegar gender (genderquake), sebuah era bangkitnya kekuasaan perempuan.

Ramalan tersebut telah menjadi kenyataan. Keterpurukan perempuan selama berabad-abad dalam berbagai segi kini telah berubah. Kesempatan yang diberikan kepada perempuan untuk mengaktualisasikan diri demikian terbuka lebar. Persamaan hak dan kesetaraan dengan kaum laki-laki pun telah banyak dirasakan kaum perempuan. Berbagai peraturan dan perundang-undangan pun pada umumnya telah tampak menjamin persamaan, kesetaraan, dan keadilan bagi perempuan tersebut. Sepintas peradaban ini tampak memberikan kemerdekaan, kebebasan, peluang ekonomi, dan memajukan derajat kaum perempuan, akan tetapi, kalau diamati secara cermat, kondisi perempuan masa kini sesungguhnya masih tak berbeda dengan zaman lampau, yakni masih mengalami penindasan dan perendahan citra dan martabat, dalam bentuknya yang berbeda.

Sampai saat ini masih sering terjadi pencitraan yang merendahkan martabat perempuan dalam berbagai bentuk. Pencitraan dan pemberian peran kepada perempuan pun sesungguhnya masih sama saja dengan zaman-zaman sebelumnya. Representasinya antara lain dapat dilihat dalam media massa dan dunia hiburan yaitu bagaimana media massa masih banyak mencitrakan kaum perempuan sebagai makhluk yang lemah, jahat, dan tempatnya masih seputar urusan dapur-sumur-kasur (urusan rumah tangga/domestik). Perempuan, selain diperbudak sebagai tenaga kerja murah, tubuhnya pun dieksploitasi sebagai alat penjual produk dan objek pemasaran produk-produk industri. Bahkan, pencitraan perempuan secara negatif itu sering muncul lewat tulisan berita di media massa yang sebetulnya justru tengah memberitakan perempuan sebagai korban dalam berita pemerkosaan misalnya.

Penyebab masih dominan pencitraan negatif, perendahan martabat, pembatasan peran, dan ketidakadilan dalam berbagai bidang pada perempuan, salah satunya adalah akses perempuan yang lemah dalam bidang pendidikan formal ataupun nonformal dan lebih memprioritaskan laki-laki daripada perempuan (Aisyah, 2008). Hal lainnya yang menjadi kendala perempuan untuk berkembang adalah faktor kemiskinan yang melanda sebagian masyarakat kita. Berbagai penelitian menunjukkan bahwa nilai-nilai gender yang antara lain disosialisasikan lewat pendidikan dan pengasuhan, menjadi kendala bagi perempuan dalam pembentukan konsep diri dan pengembangan diri secara penuh dan utuh. Berbagai penelitian menunjukkan, nilai-nilai gender telah membentuk konsep dalam diri perempuan sehingga perempuan cenderung mengalami rasa percaya diri yang rendah (self esteem), kurang mandiri (self reliance), memiliki sindrom takut sukses (fear of success syndrome) jika ditempatkan pada kondisi kompetitif dengan laki-laki, memiliki sifat ketergantungan dan meminta perlindungan (cinderella complex), dan cenderung menerima orang lain (dalam hal ini laki-laki) sebagai lebih bijaksana atau lebih kompeten daripada dirinya.

Pendidikan yang masih sarat dengan nilai gender berdampak kurang baik bagi kehidupan kaum perempuan. Dengan konsep diri yang terbentuk dalam nilai-nilai gender, perempuan masih akan terus mengalami dan membiarkan diri berada dalam ketidaksetaraan dan ketidakadilan (Aisyah, 2008). Persoalan ini tentu perlu solusi dan pemecahan serta tanggapan yang serius dari berbagai pihak. Media 
massa misalnya, Seharusnya media massa lebih menyadari fungsi media dalam bidang komunikasi, yang tidak sekedar memberi informasi, tapi juga mendidik dan mengubah sikap dan keyakinan. Lembaga-lembaga pemerintah dan nonpemerintah juga perlu terus mensosialisasikan kesadaran itu dalam berbagai sendi masyarakat. Hal itu diharapkan berimplikasi pada pendidikan di lingkungan keluarga yang lebih menanamkan konsep yang berkeadilan gender.

Tujuan dari penelitian ini adalah menduga proporsi perempuan yang bekerja di bidang Usaha Tani Padi dan membandingkannya dengan standar nasional. Sedangkan manfaat dari penelitian ini adalah: (1) Mengukur keikutsertaan Usaha Tani Padi dalam mendukung program kesetaraan gender. (2) Membandingkan nilai proporsi keterlibatan perempuan di Usaha Tani Padi dengan nilai proporsi yang ditargetkan/standard pemerintah (minimal 30\%). (3) Mengetahui faktor apa saja yang dianggap menjadi kendala berkembangnya program kesetaraan gender pada Usaha Tani Padi. Dengan adanya informasi tentang keterlibatan perempuan (gender) dalam Usaha Tani Padi dapat menambah wawasan dan referensi para pemerhati perkembangan perempuan di masyarakat serta dapat dijadikan acuan para pengambil keputusan dan kebijakan yang berkaitan dengan program peningkatan peranan perempuan dalam Pembangunan Pertanian.

\section{METODE}

\section{Sebaran Binomial}

Variabel random $X$ yang menyatakan banyaknya sukses pada n kali percobaan bernoulli mempunyai sebuah sebaran binomial dengan fungsi peluang $p(x)$, sebagai berikut

$$
\begin{aligned}
p(x) & =\left(\begin{array}{l}
n \\
x
\end{array}\right) p^{x}(1-p)^{n-x} & & x=0,1,2, \ldots, n \\
& =0 & & \text { lainnya }
\end{aligned}
$$

Parameter dari sebaran binomial adalah $n$ dan $p$, dimana $n$ adalah suatu bilangan bulat positif dan $0 \leq p \leq 1$.

Rata-rata X dapat ditentukan secara langsung sebagai

$$
\begin{aligned}
& E(X)=\sum_{x=0}^{n} x \cdot \frac{n !}{x !(n-x) !} p^{x} q^{n-x} \text { sehingga } \\
& E(X)=n p
\end{aligned}
$$

Dengan menggunakan pendekatan yang sama kita dapat menghitung varian $\mathrm{X}$ sebagai berikut

$$
\begin{aligned}
V(X) & =\sum_{x=0}^{n} x \cdot \frac{x^{2} n !}{x !(n-x) !} p^{x} q^{n-x}-(n p)^{2} \\
& =n(n-1) p^{2} \sum_{y=0}^{n-2} \frac{(n-2) !}{y !(n-2-y) !} p^{y} q^{n-2-y}+n p-(n p)^{2}
\end{aligned}
$$

Sehingga $V(X)=n p q$. Fungsi pembangkit momen untuk sebaran binomial adalah

$$
M_{x}(t)=(p e+q)^{n}
$$


Sebaran kumulatif atau fungsi sebaran binomial atau fungsi sebaran $\mathrm{G}$ adalah

$$
G(x)=\sum_{k=0}^{x}\left(\begin{array}{l}
n \\
p
\end{array}\right) p^{k}(1-p)^{n-k}
$$

\section{Pendugaan Parameter}

Dalam penelitian, populasi di mana sampel diambil, berusaha disimpulkan untuk mewakili populasi tersebut (Vincent, 1989). Untuk tujuan tersebut data yang diambil baik secara sampling maupun sensus dipelajari. Karena keterbatasan waktu, dana, serta populasi yang besar (tak hingga), maka sampel yang representatif diambil, lalu berdasarkan hasil analisis terhadap data sampel, kesimpulan mengenai populasi dibuat. Perilaku populasi yang akan ditinjau di sini hanya mengenai parameter populasi dan sampel yang digunakan adalah sampel acak. Data dari sampel dianalisis sehingga diperoleh nilai-nilai statistik atau statistic sample. Statistik sampel yang diperoleh digunakan untuk menduga parameter-parameter dari populasi (Sudjana, 2005).

Secara umum parameter populasi diberi simbul $\theta$ (baca theta) jadi $\theta$ bisa berupa rata-rata $\mu$ simpangan baku $\alpha$, proporsi $\mathrm{P}$ dan sebagainya. Jika $\theta$ yang tidak diketahui harganya diduga oleh $\theta^{\prime}$ maka $\theta^{\prime}$ dinamakan penduga titik jelas diinginkan $\theta^{\prime}=\theta$ tetapi ini hanya merupakan suatu keinginan yang ideal sifatnya, kenyataan yang terjadi adalah: (1) Penduga $\theta$ oleh $\theta^{\prime}$ terlalu tinggi. (2) Penduga $\theta$ oleh $\theta^{\prime}$ terlalu rendah.

Kedua hal ini jelas tidak diinginkan karena penduga yang baik yang diinginkan. Suatu penduga (estimator) dianggap sebagai penduga yang baik jika penduga tersebut memenuhi sifat tak bias (unbiased), mempunyai varian (ragam) minimum dan konsisten. Penduga $\theta^{\prime}$ dikatakan penduga tak bias jika rata-rata semua harga $\theta^{\prime}$ yang mungkin akan sama dengan $\theta$. Penduga beragam minimum ialah penduga dengan ragam terkecil diantara semua penduga untuk parameter yang sama. Jika $\theta_{1}^{\prime}$ dan $\theta_{2}^{\prime}$ dua penduga beragam minimum dan merupakan penduga yang baik. Misalkan $\theta^{\prime}$ penduga untuk $\theta$ yang dihitung berdasarkan sampel acak berukuran $n$. jika ukuran sampel $n$ makin besar mendekati ukuran populasi maka akan menyebabkan $\theta^{\prime}$ mendekati $\theta$ maka $\theta^{\prime}$ dijamin merupakan penduga konsisten. Penduga tak bias dan beragam minimum dinamakan penduga terbaik.

\section{Selang Kepercayaan}

Karena sering merasa kurang yakin atau kurang percaya atas hasil penduga titik ini, maka untuk lebih meyakinkan dilakukan pendugaan interval/selang atau daerah pendugaan yaitu menduga suatu parameter diantara batas-batas dua harga dengan tingkat kepercayaa yang telah ditentukan. Jika koefisien kepercayaan dinyatakan dengan $\partial$ maka besarnya $0<\partial<1$. harga $\partial$ yang digunakan tergantung pada persoalan yang dihadapi dan diyakini. Namun yang biasa digunakan ialah $0.90 ; 0.95$ atau 0.99 .

Jadi pendugaan $\theta$ yang dimaksud adalah :

$$
\mathrm{P}(\mathrm{A}<\theta<\mathrm{B})=
$$

Di mana $\mathrm{P}$ : peluang yang diiginkan; A : batas bawah pendugaan; $\mathrm{B}$ :batas atas pendugaan; $\theta$ : parameter yang diduga; : koefisien kepercayaan pendugaan

Peluang $\theta$ terletak diantara nilai A dan B sebesar . dan dalam penelitian A dan B dihitung harganya berdasarkan data sampel. 


\section{Pendugaan proporsi $\mathbf{P}$}

Populasi binomial berukuran $\mathrm{N}$ di mana terdapat propirsi $\mathrm{P}$ untuk suatu peristiwa yang terdapat dalam populasi tersebut. Bila di dalam sampel terdpat $\mathrm{n}$ kejadian dan terdapat $\mathrm{x}$ kejadian yang sukses maka proporsi atau peluang kejadian sukses adalah $\mathrm{p}=\mathrm{x} / \mathrm{n}$,

Sehingga interval/selang kepercayaannya dengan pendekatan normal dengan $\mathrm{n}$ cukup besar adalah :

$$
p \pm Z_{1 / 2 \alpha} \sqrt{\frac{p(1-P)}{n}}
$$

atau interval/selang kepercayaan untuk $\mathrm{P}$ dapat ditulis sebagai berikut:

$$
p-Z_{1 / 2 \alpha} \sqrt{\frac{p(1-p)}{n}}<P<p+Z_{1 / 2 \alpha} \sqrt{\frac{p(1-p)}{n}}
$$

\section{Pengujian Hipotesis}

Hipotesis adalah jawaban/dugaan sementara terhadap suatu permasalahan yang paling dianggap benar. Dianggap sementara karena perlu dibuktikan kebenarannya dan dianggap paling benar karena sudah berdasarkan pada pikiran yang logis dan pengetahuan yang menunjangnya. Pengujian hipotesis akan membawa kepada kesimpulan untuk menerima atau menolak hipotesis. Jadi dengan demikian hanya terdapat dua pilihan. Maka dalam statistika kita mengenal dua hipotesis yaitu $\mathrm{H}_{0}$ dan $\mathrm{H}_{1}$ (Douglas \&William, 1990)

Pasangan $\mathrm{H}_{0}$ dan $\mathrm{H}_{1}$ mempunyai daerah penerimaaan dan daerah penolakan hipotesis. Daerah penolakan hipotesis sering disebut daerah kritis. Bila kita ingin menguji suatu parameter yang diketahui $\left(\theta_{\mathrm{o}}\right)$ maka hipotesisinya adalah sebagui berikut: (1) Hipoteisi dua arah, $\mathrm{H}_{\mathrm{o}}: \theta=\theta_{\mathrm{o}}$ lawan $\mathrm{H}_{1} ; \theta \neq \theta_{\mathrm{o}}$ (2) Hipotesisi satu arah kanan, $\mathrm{H}_{\mathrm{o}}: \theta \leq \theta_{\mathrm{o}}$ lawan $\mathrm{H}_{1} ; \theta>\theta_{\mathrm{o}}$ Hipotesis ini mengandung pengertian maksimum (meningkatkan). (3) Hipotesisi Satu arah kiri, $\mathrm{H}_{0}: \theta \geq \theta_{\mathrm{o}}$ lawan $\mathrm{H}_{1} ; \theta<\theta_{\mathrm{o}}$ Hipotesis ini mengandung pengertian minimum(menurunkan)

\section{Pengujian Hipotesis Untuk Proporsi}

Hipotesisnya :

$$
H_{o}: P=P_{o} \quad \text { lawan } \quad H_{1}: P \neq P_{o}
$$

Pengujian dilakukan dengan statistic

$$
\left|Z_{H}\right|=\frac{p-P_{o}}{\sqrt{\frac{p(1-p)}{n}}}
$$

kriteria penerimaan $\mathrm{H}_{\mathrm{o}}$ adalah :

$$
\begin{aligned}
& \mathrm{H}_{\mathrm{o}} \text { diterima pada taraf } \alpha \text { jika }\left\lfloor Z_{H}\right\rfloor<\lfloor Z \alpha\rfloor \\
& \mathrm{H}_{\mathrm{o}} \text { ditolak pada taraf } \alpha \text { jika }\left\lfloor Z_{H}\right\rfloor \geq\lfloor Z \alpha\rfloor
\end{aligned}
$$




\section{HASIL DAN PEMBAHASAN}

\section{Keterlibatan Perempuan Dalam Usaha Tani Padi}

Berdasarkan data hasil penelitian, secara deskriptif proporsi petani responden sebanyak 119 orang di tiga Kabupaten Bandung (36 orang), Subang (38 orang) dan Karawang (45 orang) yang melibatkan perempuan (gender) dalam kegiatan usaha tani padi dapat disajikan dalam tabel yang merinci proporsi untuk setiap tahapan kegiatan usaha tani sebagai berikut:

Tabel 1 Proporsi Petani Responden yang Melibatkan Perempuan Dalam Usaha Tani Padi

\begin{tabular}{lcccc}
\hline Tahapan Kegiatan & $\begin{array}{c}\text { Kabupaten } \\
\text { Bandung } \\
(36 \text { resp) }\end{array}$ & $\begin{array}{c}\text { Kabupaten } \\
\text { Subang } \\
(38 \text { resp) }\end{array}$ & $\begin{array}{c}\text { Kabupaten } \\
\text { Karawang } \\
(45 \text { resp })\end{array}$ & $\begin{array}{c}\text { Keseluruhan } \\
(119 \text { resp) }\end{array}$ \\
\hline Persemaian & 33,33 & 13,16 & 4,44 & 16,00 \\
Pengolahan Lahan & 5,56 & 2,63 & 0,00 & 2,50 \\
Penanaman*) & 100,00 & 71,05 & 35,56 & 66,40 \\
Penyiangan ${ }^{*}$ & 94,44 & 68,42 & 44,44 & 67,20 \\
Pemupukan & 58,33 & 2,63 & 2,22 & 19,30 \\
PHT & 13,89 & 5,26 & 0,00 & 5,90 \\
Pengairan & 0,00 & 2,63 & 0,00 & 0,80 \\
Panen & 33,33 & 7,89 & 17,78 & 19,30 \\
Pasca Panen & 36,11 & 2,63 & 6,67 & 14,30 \\
Pengangkutan & 0,00 & 0,00 & 2,22 & 0,80 \\
Keseluruhan & 37,50 & 17,63 & 11,33 & 21,26 \\
\hline
\end{tabular}

Dari tabel di atas nampak bahwa secara keseluruhan ada $21,26 \%$ petani responden yang melibatkan perempuan dalam kegiatan usaha taninya, selanjutnya $37,50 \%$ petani responden di Kabupaten Bandung yang melibatkan perempuan dalam usaha taninya dan seterusnya diikuti Kabupaten Subang sebanyak 17,63\% petani responden dan 11,33\% petani responden dari Kabupaten Karawang. Jika diamati menurut tahapan kegiatan maka tahapan kegiatan penanaman dan penyiangan, pada umumnya petani responden melibatkan perempuan baik secara keseluruhan ataupun untuk setiap Kabupaten (semuanya di atas 35\%). Di tiga Kabupaten hampir di semua tahapan kegiatan, responden melibatkan perempuan dalam usaha tani padinya.

Tahapan kegiatan yang sama sekali tidak melibatkan perempuan, untuk Kabupaten Bandung pada tahap kegiatan pengairan dan pengangkutan, untuk Kabupaten Subang pada tahapan kegiatan pengangkutan saja, sedangkan di Kabupaten Karawang pada tahapan kegiatan pengolahan lahan, PHT dan pengairan yang sama sekali tidak melibatkan perempuan. Data di atas hanya menelaah proporsi petani responden yang melibatkan perempuan dalam usaha taninya. Secara lebih detail, berikut ditelaah kuantitas keterlibatan perempuan dalam kegiatan usaha tani padi. Dalam telaahan ini proporsi gender (perempuan) yang bekerja di usaha tani padi dihitung dengan menentukan rasio antara hari orang kerja (HOK) perempuan dengan total HOK (laki-laki + perempuan), atau

$$
\text { Proporsi }(\text { gender })=\mathrm{HOK}_{\mathrm{P}} / \mathrm{HOK}_{(\text {laki-laki }+ \text { perempuan })} * 100 \%
$$

Hasil pengamatan mengenai jumlah tenaga kerja yang bekerja di usaha tani padi yang dirinci untuk setiap kegiatan dan hari kerja laki-laki (HOK L) dan perempuan (HOP P) dapat disajikan dalam tabel berikut 
Tabel 2 Banyaknya Hari Orang Kerja (HOK) dalam Tahapan Kegiatan

\begin{tabular}{|c|c|c|c|c|c|c|c|c|}
\hline \multirow[t]{2}{*}{ Tahapan Kegiatan } & \multicolumn{2}{|c|}{ Kabupaten Bandung } & \multicolumn{2}{|c|}{ Kabupaten Subang } & \multicolumn{2}{|c|}{$\begin{array}{l}\text { Kabupaten } \\
\text { Karawang }\end{array}$} & \multicolumn{2}{|c|}{ Keseluruhan } \\
\hline & HOK P & HOK L & HOK P & HOK L & HOK P & HOK L & HOK P & HOK L \\
\hline Persemaian & 45 & 101 & 19 & 1.228 & 2 & 104 & 66 & 1.433 \\
\hline Proporsi (\%) & 30,82 & & 1,52 & & 1,89 & & 4,40 & \\
\hline Pengolahan Lahan & 9 & 337 & 1 & 5.294 & - & 954 & 1 & 6.248 \\
\hline Proporsi (\%) & 2,60 & & 0,02 & & 0,00 & & 0,02 & \\
\hline Penanaman & 528 & 144 & 1.792 & 1.034 & 195 & 171 & 2.515 & 1.349 \\
\hline Proporsi (\%) & 78,57 & & 63,41 & & 53,28 & & 65,09 & \\
\hline Penyiangan & 582 & 448 & 1.844 & 1.198 & 182 & 275 & 2.608 & 1.921 \\
\hline Proporsi (\%) & 56,50 & & 60,62 & & 39,82 & & 57,58 & \\
\hline Pemupukan & 106 & 150 & 5 & 2.272 & 2 & 194 & 113 & 2.616 \\
\hline Proporsi (\%) & 41,41 & & 0,22 & & 1,02 & & 4,14 & \\
\hline PHT & 6 & 143 & 16 & 1.370 & - & 256 & 22 & 1.769 \\
\hline Proporsi (\%) & 4,03 & & 1,15 & & 0,00 & & 1,23 & \\
\hline Pengairan & - & 699 & 100 & 974 & - & 54 & 100 & 1.727 \\
\hline Proporsi (\%) & 0,00 & & 9,31 & & 0,00 & & 5,47 & \\
\hline Panen & 81 & 69 & 518 & 307 & 73 & 69 & 672 & 445 \\
\hline Proporsi (\%) & 54,00 & & 62,79 & & 51,41 & & 60,16 & \\
\hline Pasca Panen & 57 & 27 & 90 & 813 & 12 & 41 & 159 & 881 \\
\hline Proporsi (\%) & 67,86 & & 9,97 & & 22,64 & & 15,29 & \\
\hline Pengangkutan & - & 72 & - & 32 & 1 & 42 & 1 & 146 \\
\hline Proporsi (\%) & 0,00 & & 0,00 & & 2,33 & & 0,68 & \\
\hline Keseluruhan & 1.414 & 2.190 & 4.385 & 14.522 & 467 & 2.160 & 6.257 & 18.535 \\
\hline Proporsi (\%) & 39,23 & & 23,19 & & 17,78 & & 25,24 & \\
\hline
\end{tabular}

Untuk lebih jelasnya, nilai proporsi tenaga kerja perempuan yang bekerja di usaha tani padi dari tabel di atas dipindahkan ke tabel di bawah ini

Tabel 3 Proporsi Perempuan (Gender) Yang Bekerja di Usaha Tani Padi

\begin{tabular}{lcccc} 
& & & \multicolumn{2}{c}{ Dalam persen (\%) } \\
\hline \multicolumn{1}{c}{ Tahapan Kegiatan } & Bandung & Subang & Karawang & Keseluruhan \\
\hline Persemaian & 30,82 & 1,52 & 1,89 & 4,40 \\
Pengolahan Lahan & 2,60 & 0,02 & 0,00 & 0,15 \\
Penanaman & 78,57 & 63,41 & 53,28 & 65,09 \\
Penyiangan & 56,50 & 60,62 & 39,82 & 57,58 \\
Pemupukan & 41,41 & 0,22 & 1,02 & 4,14 \\
PHT & 4,03 & 1,15 & 0,00 & 1,23 \\
Pengairan & 0,00 & 9,31 & 0,00 & 5,47 \\
Panen & 54,00 & 62,79 & 51,41 & 60,16 \\
Pasca Panen & 67,86 & 9,97 & 22,64 & 15,29 \\
Pengangkutan & 0,00 & 0,00 & 2,33 & 0,68 \\
Keseluruhan & 39,23 & 23,19 & 17,78 & 25,24 \\
\hline
\end{tabular}

Jika dilihat kuantitas dari tenaga kerja perempuan yang bekerja pada usaha tani padi seperti dalam tabel di atas yang merupakan kondisi tenaga kerja yang bekerja di sawah 119 petani responden ada sebanyak 24.792 HOK (6.257 HOK perempuan dan 18.535 HOK Laki-laki). Jadi proporsi perempuan yang bekerja di usaha tani padi tersebut secara keseluruhan ada sebanyak 25,24\%, sedangkan keragaan di setiap Kabupaten ada 39,78\% perempuan untuk Kabupaten Bandung, 23,19\% di Kabupaten Subang dan 17,78\% di Kabupaten Karawang. Terlihat bahwa Kabupaten Bandung paling tinggi proporsinya dan di atas standard nasional minimal 30\%, sedangkan Kabupaten Subang dan Karawang keragaannya masih di bawah standard nasional. Bila ditelaah menurut tahapan kegiatan, nampak untuk tahap penanaman, penyiangan dan kegiatan panen tenaga kerja perempuan/gender baik secara keseluruhan ataupun di setiap Kabupaten cukup dominan dan paling rendah $40 \%(39,82 \%)$. Untuk tahap kegiatan pasca panen peranan perempuan di Kabupaten Bandung cukup dominan dan mencapai 67,86\% dan Karawang mencapai 22,64\%. Untuk kegiatan persemaian dan pemupukan di Kabupaten Bandung cukup dominan mencapai 30,82\% dan 41,41\%, sedangkan di Kabupaten Subang dan Karawang peranan tenaga kerja perempuan kurang nampak dan cenderung tidak ada (dibawah 5\%). Untuk kegiatan pengolahan lahan, pengairan dan pengangkutan juga tidak 
nampak dan kurang dari 3\%, hanya untuk Kabupaten Subang kegiatan pengairan peranan perempuan mencapai 9,31\%.

Peranan tenaga kerja perempuan pada tahap kegiatan pengolahan lahan relatif tidak ada, karena pekerjaannya cukup berat dan pada umumnya laki-lakilah yang berperan atau banyak juga petani responden yang menggunakan jasa traktor. Dalam tahapan kegiatan pengangkutan tidak hanya perempuan yang peranannya kurang tetapi tenaga kerja laki-laki juga kurang nampak, hal ini diakibatkan karena petani cenderung menjual hasil panennya dan tidak ada lagi kegiatan pengangkutan.

\section{Uji Hipotesis dan Pendugaan Selang Untuk Proporsi Gender Pada Usaha Tani Padi}

Untuk memberikan gambaran yang lebih detail lagi tentang peranan perempuan dalam usaha tani padi, berikut diberikan kajian secara analitik dengan membandingkan keragaan proporsi perempuan yang bekerja di lahan petani responden sebagai hasil pengamatan dengan proporsi kesetaraan gender standar nasional minimal $30 \%$.

Dengan mengacu pada ketentuan di atas, bentuk hipotesis yang diuji adalah :

$\mathrm{H}_{\mathrm{o}}: \mathrm{P} \leq \mathrm{P}_{\mathrm{o}}$ dengan $\mathrm{P}_{\mathrm{o}}=0,30$ dan $\mathrm{H}_{1}: \mathrm{P}>\mathrm{P}_{\mathrm{o}}$. Untuk menguji hipotesis tersebut, digunakan statistic

$$
Z_{\text {hit }}=\frac{p-P_{o}}{\sqrt{\frac{p(1-p)}{n}}}
$$

dan diperoleh hasil pengujian seperti dalam tabel di bawah ini

Tabel 4 Hasil Perhitungan Untuk Pengujian Proporsi Gender

\begin{tabular}{|c|c|c|c|c|}
\hline $\begin{array}{c}\text { Kabupaten/Tahapan } \\
\text { Kegiatan }\end{array}$ & Total HOK & Proporsi (p) & Nilai Z & Keterangan \\
\hline \multicolumn{5}{|l|}{ Kabupaten Bandung } \\
\hline Persemaian & 146 & 0,3082 & $\left.0,22^{*}\right)$ & masih $<30 \%$ \\
\hline Penanaman & 672 & 0,7857 & 27,48 & di atas $30 \%$ \\
\hline Penyiangan & 1030 & 0,565 & 18,56 & di atas $30 \%$ \\
\hline Pemupukan & 256 & 0,4141 & 3,98 & di atas $30 \%$ \\
\hline Panen & 150 & 0,54 & 6,41 & di atas $30 \%$ \\
\hline Pasca Panen & 84 & 0,6786 & 7,57 & di atas $30 \%$ \\
\hline Keseluruhan & 3.604 & 0,3923 & 12,09 & di atas $30 \%$ \\
\hline \multicolumn{5}{|l|}{ Kabupaten Subang } \\
\hline Penanaman & 2.826 & 0,6341 & 38,76 & di atas $30 \%$ \\
\hline Penyiangan & 3.042 & 0,6062 & 36,85 & di atas $30 \%$ \\
\hline Panen & 825 & 0,6279 & 20,55 & di atas $30 \%$ \\
\hline Keseluruhan & 18.907 & 0,2319 & $\left.-20,43^{*}\right)$ & masih $<30 \%$ \\
\hline \multicolumn{5}{|l|}{ Kabupaten Karawang } \\
\hline Penanaman & 366 & 0,5328 & 9,72 & di atas $30 \%$ \\
\hline Penyiangan & 457 & 0,3982 & 4,58 & di atas $30 \%$ \\
\hline Panen & 142 & 0,5141 & 5,57 & di atas $30 \%$ \\
\hline Pasca Panen & 53 & 0,2264 & $-1,17^{*}$ & masih $<30 \%$ \\
\hline Keseluruhan & 2627 & 0,1778 & $-13,67^{*}$ & masih $<30 \%$ \\
\hline \multicolumn{5}{|l|}{ Tiga Kabupaten Setiap } \\
\hline Penanaman & 3.864 & 0,6509 & 47,60 & di atas $30 \%$ \\
\hline Penyiangan & 4529 & 0,5758 & 40,50 & di atas $30 \%$ \\
\hline Panen & 1117 & 0,6016 & 22,00 & di atas $30 \%$ \\
\hline Keseluruhan & 24.792 & 0,2524 & $\left.-16,36^{*}\right)$ & masih $<30 \%$ \\
\hline
\end{tabular}




\section{Pendugaan selang proporsi perempuan yang bekerja di Usaha Tani Padi}

Pendugaan selang proporsi perempuan yang bekerja di setiap tahapan kegiatan Usaha Tani Padi di tiga Kabupaten ditempuh dengan menggunakan taraf nyata $5 \%$ dan $\mathrm{Z}_{0,025}=1,96$

atau $\quad \mathrm{p} \pm 1,96 \sqrt{\frac{(0,30)(1-0,30)}{n}}$

Kisaran/interval proporsi sebagai hasil kajian dari data pengamatan disajikan dalam tabel di bawah ini dengan Selang Proporsi terdapat pada dua kolom terakhir.

Tabel 5 Hasil Perhitungan Untuk Pendugaan Proporsi Gender

\begin{tabular}{|c|c|c|c|c|c|}
\hline $\begin{array}{c}\text { Kabupaten/ } \\
\text { Tahapan Kegiatan }\end{array}$ & $\begin{array}{l}\text { Total } \\
\text { HOK }\end{array}$ & Proporsi & Deviasi & $\begin{array}{l}\text { Batas } \\
\text { Bawah }\end{array}$ & $\begin{array}{l}\text { Batas } \\
\text { Atas }\end{array}$ \\
\hline \multicolumn{6}{|l|}{ Kabupaten Bandung } \\
\hline Persemaian $\left.{ }^{\star}\right)$ & 146 & 0,3082 & 0,074 & 0,23387 & 0,3825 \\
\hline Penanaman & 672 & 0,7857 & 0,035 & 0,75105 & 0,8203 \\
\hline Penyiangan & 1030 & 0,565 & 0,028 & 0,53701 & 0,5930 \\
\hline Pemupukan & 256 & 0,4141 & 0,056 & 0,35796 & 0,4702 \\
\hline Panen & 150 & 0,54 & 0,073 & 0,46666 & 0,6133 \\
\hline Pasca Panen & 84 & 0,6786 & 0,098 & 0,58060 & 0,7766 \\
\hline Keseluruhan & 3.604 & 0,3923 & 0,015 & 0,37734 & 0,4073 \\
\hline \multicolumn{6}{|l|}{ Kabupaten Subang } \\
\hline Penanaman & 2.826 & 0,6341 & 0,017 & 0,61720 & 0,6510 \\
\hline Penyiangan & 3.042 & 0,6062 & 0,016 & 0,58992 & 0,6225 \\
\hline Panen & 825 & 0,6279 & 0,031 & 0,59663 & 0,6592 \\
\hline Keseluruhan $\left.^{\star *}\right)$ & 18.907 & 0,2319 & 0,007 & 0,22537 & 0,2384 \\
\hline \multicolumn{6}{|l|}{ Kabupaten Karawang } \\
\hline Penanaman & 366 & 0,5328 & 0,047 & 0,48585 & 0,5797 \\
\hline Penyiangan & 457 & 0,3982 & 0,042 & 0,35618 & 0,4402 \\
\hline Panen & 142 & 0,5141 & 0,075 & 0,43873 & 0,5895 \\
\hline Pasca Panen ${ }^{*}$ & 53 & 0,2264 & 0,123 & 0,10302 & 0,3498 \\
\hline Keseluruhan $^{\star \star)}$ & 2627 & 0,1778 & 0,018 & 0,16028 & 0,1953 \\
\hline \multicolumn{6}{|c|}{ Tiga Kabupaten Setiap Tahapan } \\
\hline Penanaman & 3.864 & 0,6509 & 0,014 & 0,63645 & 0,6653 \\
\hline Penyiangan & 4529 & 0,5758 & 0,013 & 0,56245 & 0,5891 \\
\hline Panen & 1117 & 0,6016 & 0,027 & 0,57473 & 0,6285 \\
\hline Keseluruhan $\left.^{\star \star}\right)$ & 24.792 & 0,2524 & 0,006 & 0,24670 & 0,2581 \\
\hline
\end{tabular}

\section{SIMPULAN}

Dalam Usaha Tani Padi, peranan perempuan/gender sudah cukup dominan pada tahapan kegiatan penanaman, penyiangan dan kegiatan panen. Khusus untuk Kabupaten Bandung pada tahapan kegiatan persemaian, pemupukan dan pasca panen peranan perempuan juga cukup dominan. Jadi Kabupaten Bandung relatif lebih mencapai target yang ditetapkan oleh pemerintah dibandingkan Kabupaten Subang dan Karawang. Tahapan kegiatan yang kurang melibatkan tenaga kerja perempuan adalah pengolahan lahan, PHT, pengairan dan pengangkutan. Peranan tenaga kerja perempuan pada tahap kegiatan pengolahan lahan relatif tidak ada, karena pekerjaannya cukup berat dan pada umumnya laki-laki yang berperan atau banyak juga petani responden yang menggunakan jasa traktor. Dalam tahapan kegiatan pengangkutan tidak hanya perempuan yang peranannya kurang tetapi tenaga kerja laki-laki juga kurang nampak, hal ini diakibatkan karena petani cenderung menjual hasil panennya dan tidak ada lagi kegiatan pengangkutan. 


\section{DAFTAR PUSTAKA}

Aisyah, N. L. (2008). Pendidikan Adil Gender. Makalah Seminar Kesetaraan Gender. Bandung, UPI Bandung

Douglas, M. C., William, H. W. (1990). Probabilita Dan Statistik Dalam Ilmu Rekayasa Dan Manajemen. Edisi ke-2, Jakarta: UI-PRESS.

Sudjana. (2005). Metode Satistika. Bandung: Tarsito.

Vincent, G. (1989). Statistika. Bandung: Tarsito. 